\title{
Gross deletions/duplications in PROS1 are relatively common in point mutation-negative hereditary protein $S$ deficiency
}

\author{
Maria C. Pintao $\cdot$ A. A. Garcia $\cdot$ D. Borgel $\cdot$ \\ M. Alhenc-Gelas $\cdot$ C. A. Spek $\cdot$ M. C. H. de Visser • \\ S. Gandrille $\cdot$ Pieter H. Reitsma
}

Received: 23 March 2009 / Accepted: 14 May 2009 / Published online: 23 May 2009

(c) The Author(s) 2009. This article is published with open access at Springerlink.com

\begin{abstract}
Hereditary protein S (PS) deficiency is an autosomal disorder caused by mutations in the PS gene (PROS1). Conventional PCR-based mutation detection identifies PROS1 point mutations in approximately $50 \%$ of the cases. To verify if gross copy number variations (CNVs) are often present in point mutation-negative hereditary PS deficiency we used multiplex ligation-dependent probe amplification (MLPA) as a detection tool in samples
\end{abstract}

M. C. Pintao and A. A. Garcia contributed equally to this article.

M. C. Pintao - A. A. Garcia - M. C. H. de Visser .

P. H. Reitsma ( $\square)$

Einthoven Laboratory for Experimental Vascular Medicine,

C2-143, Department of Thrombosis and Haemostasis,

Leiden University Medical Center, P.O. Box 9600,

2300 RC Leiden, The Netherlands

e-mail: p.h.reitsma@lumc.nl

M. C. Pintao

e-mail: m.c.t.pintao@lumc.nl

D. Borgel

IFR 141, Faculty of Pharmacy,

University Paris Sud, Orsay, France

D. Borgel · M. Alhenc-Gelas · S. Gandrille

INSERM Unité de Recherche 765, Paris, France

M. Alhenc-Gelas $\cdot$ S. Gandrille

AP-HP Hôpital Européen Georges Pompidou,

Service d'Hématologie Biologique, Paris, France

C. A. Spek

Center for Experimental and Molecular Medicine,

Academic Medical Center, Amsterdam, The Netherlands

S. Gandrille

UFR des Sciences Pharmaceutiques et Biologiques,

Université Paris Descartes, Paris, France from individuals with a high probability of having true PS deficiency. To this end, DNA samples from nine PS deficient probands with family members (seven type I and two type III) and nine isolated probands (three type I and six type III), in whom PROS1 mutations were not found by DNA sequencing, were evaluated. An independent quantitative PCR (qPCR) was performed to confirm the findings of the MLPA assay. Family members were also tested when DNA was available. Gross abnormalities of PROSI were found in six out of eighteen probands. In three probands complete deletion of the gene was detected. Two probands had a partial deletion involving different parts of the gene (one from exon 4 through 9 and another from exon 9 through 11). One family showed a duplication of part of PROS1. qPCR analysis was in accordance with these results. In conclusion, this study substantiates that gross gene abnormalities in PROS1 are relatively common in hereditary PS deficient patients and that MLPA is a useful tool for direct screening of CNVs in PROS1 point mutation-negative individuals.

\section{Introduction}

Protein S (PS; MIM 176880) is a vitamin K-dependent plasma glycoprotein that functions as a non-enzymatic cofactor of activated protein C (APC) in the proteolytic degradation of activated factor $\mathrm{V}$ and activated factor VIII (Dahlbäck 2000; Esmon 1987). Approximately 60\% of PS is non-covalently bound to $\mathrm{C} 4 \mathrm{~b}$-binding protein (C4BP). The remaining $40 \%$ circulates as free PS and represents the biologically active portion of circulating PS (Dahlbäck and Stenflo 1981). It was demonstrated recently that the C4BPbound PS may play a role in the inactivation of activated factor V (Maurissen et al. 2008). 
Inherited PS deficiency is considered to be an autosomal haploinsufficiency disorder that is associated with venous thrombosis. It is generally classified in three categories: (a) type I, characterized by a quantitative deficiency of total and free PS antigen; (b) type II, characterized by a qualitative defect with reduced APC cofactor activity but normal levels of total and free PS antigen; (c) type III, characterized by a quantitative deficiency of free PS antigen only (Bertina 1990).

The precise prevalence of PS deficiency remains unknown because it is quite rare and because a correct diagnosis with plasma assays is complicated. The latter is the result of limitations of the laboratory techniques and of the fact that PS levels are influenced by acquired and hereditary factors, such as age, sex, pregnancy, oral contraceptive use, vitamin $\mathrm{K}$ intake and polymorphisms in the PS gene (Persson et al. 2003; Ten Kate and van der Meer 2008). In thrombotic patients, the estimated prevalence of inherited PS deficiency varies from $2-5 \%$ in unselected patients to $1-13 \%$ in selected patients from thrombophilia families (Lane et al. 1996; Seligsohn and Lubetsky 2001; Ten Kate and van der Meer 2008), while in the general population estimates differ sharply between 0.03 and $0.13 \%$ (Dykes et al. 2001).

PS is encoded by PROS1 which is approximately $80 \mathrm{~kb}$ long and consists of 15 exons and 14 introns. PROSI is located near the centromere of chromosome 3 at position 3q11.2 (Schmidel et al. 1990). A transcriptionally silent pseudogene (PROSP) is located close to PROS1 and is 95 and $97 \%$ similar to PROS1 for introns and exons, respectively, except for exon 1, which is absent in PROSP (Ploos van Amstel et al. 1987, 1990). Both the large size of the gene and the presence of the pseudogene complicate the study of PROS1 mutations.

Screening for PROS1 mutations has been performed in a number of studies (Espinosa-Parrilla et al. 1999; Gómez et al. 1995; Johansson et al. 2005; Reitsma et al. 1994). Many of these were based on a strategy of resequencing exons and flanking intronic regions. More than 200 different PROS1 mutations have been described up to now. The vast majority of these are missense or nonsense mutations and only a few are gross deletions or duplications (Gandrille et al. 2000; Stenson et al. 2009; Ten Kate and van der Meer 2008). In type I and III PS deficiency, the mutations are spread throughout PROS1, while type II is usually caused by missense mutations in exons 5 and 8 , which encode the epidermal growth factor (EGF)-like domains (García de Frutos et al. 2007). Coexistence of type I and III deficiencies in the same family has been described and seems to be explained by the observation that total PS levels increase with age, whereas free PS levels are not influenced by age (Simmonds et al. 1997).

Overall, PROS1 mutations have been identified in only $50 \%$ of the PS deficient families that were analyzed
(Johansson et al. 2005; Lanke et al. 2004). The reason for this is poorly understood. Segregation of genetic markers in PS deficient families suggested that mutations should be sought in or close to PROS1 (Lanke et al. 2004). Since large deletions and duplications are not detected with a PCR-based DNA sequencing approach, other techniques were explored. Using segregation analysis, Johansson et al. indirectly detected large deletions in several mutationnegative patients with PS deficiency (Johansson et al. 2005). Furthermore, three case-reports have been published that used a multiplex ligation-dependent probe amplification analysis (MLPA) which detected two large deletions (Yin et al. 2007; Yoo et al. 2009) and one large duplication (Choung et al. 2008) in patients with PS deficiency. MLPA is a technique that allows the evaluation of multiple fragments from a gene in a single reaction and can detect copy number variation $(\mathrm{CNV})$ involving one or more exons (Schouten et al. 2002).

The aim of this study was to investigate whether large deletions or duplications are common in hereditary PS deficiency and whether MLPA represents a useful screening tool in individuals with point mutation-negative PS deficiency.

\section{Materials and methods}

\section{Subjects}

DNA samples were obtained from families or isolated probands who were recruited by a French network which was set up to study PS deficiency. The probands were consecutive patients who were referred to a specialized clinical hematology laboratory because they had at least one episode of thrombosis of unidentified cause. The clinical criteria for including PS deficient thrombotic patients (probands) and the PCR-based DNA resequencing results have been described before in three reports (Borgel et al. 1996; Duchemin et al. 1996; Gandrille et al. 1995). The diagnosis of PS deficiency was based on a total PS level below $65 \%$ of normal, as measured with an immunologic assay (Asserachrom Protein S; Diagnostica Stago, Asnières, France), and/or a free PS level below $65 \%$ of normal, as measured with the same immunologic assay after precipitation of the C4BP/PS complex with polyethylene glycol (Comp et al. 1986). Sex, age, and pregnancy were not taken into account when assigning a deficiency state. Patients using vitamin $\mathrm{K}$ antagonists were excluded from analysis. Patients who were classified as type I or type III PS deficient were asked to provide blood for DNA analysis and a second PS measurement. Only DNA from patients in whom PS deficiency was confirmed by a second assay was analyzed. Family studies were undertaken whenever possible. 
For the present study, PS deficient subjects of the French network were selected with a high probability of having a hereditary PS deficiency, either by having a family history of PS deficiency transmission, or by having very low PS measurements. In all of them, no mutation was found by exon-targeted sequencing of PROS1. The panel (Table 1) comprised eighteen probands out of which ten were type I and eight were type III PS deficient. Nine were isolated probands and nine were probands with thirty family members including nine non-PS deficient and twenty-one PS deficient subjects. Families 1 and 2 (Gandrille et al. 1995) (Borgel et al. 1996) and families 4 and 8 (Duchemin et al. 1996) were part of previous reports of the French network. All other families and probands were not included in previous publications. PS measurements for the probands are presented in Table 1.

\section{MLPA}

MLPA was performed as described before (Schouten et al. 2002) using the SALSA MLPA KIT P112 PROS1 (MRCHolland, Amsterdam, The Netherlands). Briefly, MLPA is a PCR-based technique for the relative quantification of genomic DNA sequences. The P112 PROS1 kit contains thirteen probes that target twelve of the fifteen exons of PROS1, one probe targeting a segment of DNA which is located $6.5 \mathrm{~kb}$ in front of the first exon of PROS1, one probe targeting exon 4 of the pseudogene (PROSP) and twenty-one control probes targeting different chromosomes (chromosome 1, 2, 3, 5, 7, 9, 10, 12, 14, 15, 16, 18, 19, 21). After amplification, fragments were analyzed on an ABI PRISM $^{\circledR}$ 3730xl Analyzer (Applied Biosystems, Foster City, CA, USA) and the GeneMapper software (Applied Biosystems, Foster City, CA, USA) was used for visualizing peaks and calculating peak areas. Calculation of relative probe signals was adapted from Schouten et al. (2002) and obtained by dividing the peak area of a given exon probe by the peak area of flanking control probes. The results of test samples were compared to the results of two different pools of control DNA samples that were run concurrently. Deletions and duplications are apparent by a 35-50\% variation of relative peak area of the amplification product of a given probe in comparison to the relative peak area of the same probe for the control samples. When a deletion or

Table 1 Characteristics of probands with PS deficiency and MLPA results

\begin{tabular}{|c|c|c|c|c|c|c|c|c|}
\hline \multirow[t]{2}{*}{ Family } & \multirow[t]{2}{*}{ Proband } & \multicolumn{2}{|c|}{$\begin{array}{l}\text { Number of family member } \\
\text { available for analysis }\end{array}$} & \multirow[t]{2}{*}{$\begin{array}{l}\text { Total } \\
\text { PS }(\%)^{\mathrm{a}}\end{array}$} & \multirow[t]{2}{*}{$\begin{array}{l}\text { Free } \\
\text { PS }(\%)^{\mathrm{a}}\end{array}$} & \multirow[t]{2}{*}{$\begin{array}{l}\text { PS } \\
\text { deficiency }\end{array}$} & \multirow[t]{2}{*}{$\mathrm{CNV}$ in $P R O S 1^{\mathrm{b}}$} & \multirow[t]{2}{*}{ Exons } \\
\hline & & PS deficient & Not PS deficient & & & & & \\
\hline 1 & $\mathrm{~S} 1$ & 1 & 0 & 45 & 40 & Type I & Not found & - \\
\hline 2 & $\mathrm{~S} 3$ & 0 & 3 & 55 & 38 & Type I & c.(210_294)_(1323_1360)dup & $4-11^{\mathrm{c}}$ \\
\hline 3 & $\mathrm{~S} 11$ & 0 & 0 & 55 & 23 & Type I & c.(697_909)_(1323_1360)del & $9-11^{\mathrm{d}}$ \\
\hline 4 & S17 & 1 & 0 & 63 & 22 & Type I & c. $\left(? \_-133\right) \_\left(* 1 \_?\right)$ del & All \\
\hline 5 & $\mathrm{~S} 20$ & 1 & 1 & 55 & 42 & Type I & Not found & - \\
\hline 6 & $\mathrm{~S} 24$ & 2 & 1 & 66 & 20 & Type III & Not found & - \\
\hline 7 & S27 & 5 & 0 & 19 & 37 & Type I & Not found & - \\
\hline 8 & $\mathrm{~S} 33$ & 3 & 1 & 18 & 15 & Type I & c. $\left(?{ }_{-}-133\right) \_\left(* 1 \_?\right) \mathrm{del}^{\mathrm{e}}$ & All \\
\hline 9 & $\mathrm{~S} 38$ & 0 & 0 & 84 & 31 & Type III & Not found & - \\
\hline 10 & S39 & 0 & 0 & 130 & 15 & Type III & Not found & - \\
\hline 11 & $\mathrm{~S} 40$ & 0 & 0 & 65 & 20 & Type III & Not found & - \\
\hline 12 & $\mathrm{~S} 41$ & 0 & 0 & 80 & 15 & Type III & c.(210_294)_(929_1010)del & $4-9^{c}$ \\
\hline 13 & $\mathrm{~S} 42$ & 0 & 0 & 50 & 25 & Type I & Not found & - \\
\hline 14 & S43 & 0 & 0 & 76 & 19 & Type III & Not found & - \\
\hline 15 & S44 & 0 & 0 & 59 & 25 & Type I & c. $\left(? \_-133\right) \_\left(* 1 \_?\right)$ del & All \\
\hline 16 & S45 & 0 & 0 & 72 & 45 & Type III & Not found & - \\
\hline 17 & S46 & 3 & 0 & 56 & 21 & Type I & Not found & - \\
\hline 18 & $\mathrm{~S} 52$ & 5 & 3 & 71 & 13 & Type III & Not found & - \\
\hline
\end{tabular}

\footnotetext{
${ }^{a}$ Normal PS level: $\geq 65 \%$

b NM_000313.2, according to the guidelines of Mutation Nomenclature Homepage at the HGVS website (den Dunnen and Antonarakis 2000 at http://www.hgvs.org/mutnomen accessed 12 May 2009)

c The involvement of exon 3 can not be ruled out as there is no probe for this exon in P112 MLPA kit

d The involvement of exon 8 can not be ruled out as there is no probe for this exon in P112 MLPA kit

${ }^{\mathrm{e}}$ For this family, qPCR suggests that GPR15 is also deleted. Therefore, at least $5 \mathrm{Mb}$ upstream from exon 1 of PROS1 are deleted
} 
duplication was suspected, the assay was repeated for confirmation.

\section{Quantitative PCR analysis}

A qPCR analysis was performed for patients that presented with deletions in the MLPA analysis (Hoebeeck et al. 2005; Johansson et al. 2005; Yin et al. 2007). Primers were designed for intron 4, intron 6, and intron 10 of PROS1, avoiding concurrent amplification of PROSP. For normalization, we designed primers for genes of which the copy number is not known to vary, namely GPR15, ZIC4 (both on chromosome 3) and PRR15 (on chromosome 7). Primers are described in Table 2 . Nine family members with normal values of PS were evaluated as controls. The qPCR was performed using SYBR-Green detector on an ABI Prism 7900HT Fast Real Time PCR system (Applied Biosystems, Foster City, CA, USA). Reaction mixtures contained $1 \times$ SYBR-Green ${ }^{\circledR}$ PCR Master Mix (Applied Biosystems, Foster City, CA, USA), $200 \mathrm{nM}$ of each primer and $1 \mathrm{ng} / \mu \mathrm{l}$ of template DNA in a total volume of $25 \mu \mathrm{l}$. Samples were analyzed in duplicate and a second run was performed to confirm the results. Cycling conditions were as follows: $10 \mathrm{~min}$ on $95^{\circ} \mathrm{C}, 40$ cycles consisting of $94^{\circ} \mathrm{C}$ for $15 \mathrm{~s}$ and $60^{\circ} \mathrm{C}$ for $1 \mathrm{~min}$. Data were analyzed with the ABI Prism 7900 sequence detection system (version 2.2.2; Applied Biosystems, Foster City, CA, USA) and quantified with the comparative threshold cycle method using the genes mentioned above as a reference (de Visser et al. 2008). The fold difference expected for a normal individual with one copy of the gene per haploid is 1 . The expected fold difference for an individual with a deletion in one of the chromosomes is 0.5 and the fold difference for an individual with a duplication will be 1.5 .

\section{Results}

MLPA analysis

CNV was detected in six out of eighteen PS deficient probands (Table 1). Of these six individuals five were classified as type I deficient and one as type III deficient. Complete deletion of PROS1 was detected in three probands with type I deficiency. Two probands appeared to have a partial deletion involving different parts of the gene; one from exon 4 through 9 (type III deficiency) and another from exon 9 through 11 (type I deficiency). In one family with type I deficiency a duplication of at least exon 4 through 11 was detected. Three out of six probands with a CNV had other family members available for analysis and three were isolated probands. In the family members (family 2, 4 and 8) the CNVs were shown to co-segregate with PS deficiency (Fig. 1). A representative example of how a gene deletion shows up in a MLPA analysis is given in Fig. 2.

Table 2 Primers for quantitative PCR technique

\begin{tabular}{llll}
\hline Gene product & GeneID & Forward primer & Reverse primer \\
\hline PROS1 intron4 & 5627 & 5'GTCCCACCAGTTTGGAAGGA & 5'GCAGGCATCCACTCTGATCTTA \\
PROS1 intron6 & 5627 & 5'GGTCCAAAGGCCAATCTGTTAT & 5'CCCATACCAGCAGACACTACCA \\
PROS1 intron10 & 5627 & 5'GCCATGATGAGGATGTGGATT & 5'CCACAAAGCCATTAGCTTCTGA \\
GPR15 & 2838 & 5'CATTGTGACCTGCTACTGTTGCA & 5'TTTGTTGTGCTTTCCTGATTGC \\
ZIC4 & 84107 & 5'CGGTTTCCCTGAGTTCTTTTCA & 5'GCCAGGATTCCAGTGTGACCTA \\
PRR15 & 222171 & 5'CCCAGGTGCTTATCCAAAGG & 5'TGACTGTAGATGGACGCCAAA \\
\hline
\end{tabular}
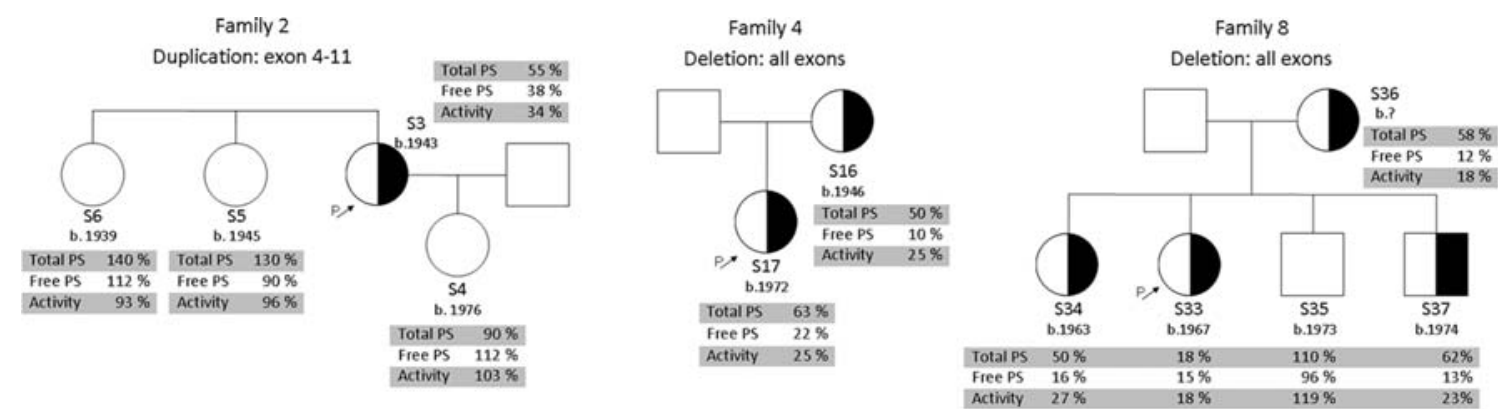

Fig. 1 Family trees of probands that presented with copy number variation in the MLPA analysis showing co-segregation of deletions/duplications with PS deficiency. Arrows indicate probands $(P)$. Year of birth $(b$.$) is indicated together with sample number$ 




Fig. 2 Example of a MLPA electropherogram of a patient with a PROS1 deletion (top) and a control (bottom). Exons peaks are highlighted by bars and indicated by their names. Non-highlighted peaks correspond to control genes. $x$-axis represents the fragment size in base pair. Note that the height of the exon peaks compared to the flanking control peaks is lower in the patient in comparison to the control. Tak-

qPCR analysis

As a confirmation tool, qPCR was performed for PROSI introns 4,6 and 10, and three genes elsewhere in the genome were used for normalization. Nine out of ten individuals (five probands and four family members) who showed variation in the MLPA analysis were evaluated. DNA from proband $\mathrm{S} 3$, with a putative partial duplication by MLPA analysis, was not available in sufficient quantities for further tests.

We performed analyzes using three different control genes for normalization. When ZIC4 (on chromosome 3) and PRR 15 (on chromosome 7) were used for normalization, the qPCR confirmed all MLPA results. However, when GPR15 (chromosome 3) was used as reference gene, one of the families (family 8, samples S33, S34, S36 and S37) presented with a fold change of 1 suggesting that the deletion also involved this control gene. GPR15 is located on chromosome 3 at location 3q11.2-q13.1, approximately $5 \mathrm{Mb}$ upstream (telomeric) from exon 1 of PROS1. Because the qPCR returned a fold change of 0.5 when ZIC4, which is far upstream from exon 1 of PROS1, and when PRR15, which is on chromosome 7, were used for normalization, we conclude that the deletion in this family involves ing exon 6 as an example, the arrows indicate the flanking control genes to which exon 6 is compared. For objective comparison we used the relative peak area, which was calculated by the division of a given exon peak area by the sum of the peak areas of flanking control genes. Variation of more than $35 \%$ is considered a deletion (if less) or a duplication (if more)

PROS1 and GPR15, including at least 20 confirmed genes in between.

\section{Discussion}

In this study, we evaluated eighteen probands with PS deficiency in whom mutations were not found by exon targeted sequencing. Ten out of eighteen probands were type I deficient and eight were type III deficient. Nine of the probands had family members that could be studied. In six out of eighteen probands (33\%) we discovered deletions or duplications in PROS1 with the MLPA method. Of these six, one had type III deficiency (isolated proband) and the others had type I deficiency (two isolated probands and three probands with family members).

To confirm the deletions found by MLPA, we performed a qPCR analysis using primers that were designed for selected introns and we chose three genes for normalization (GPR15 and ZIC4 on chromosome 3 and PRR15 on chromosome 7). Surprisingly, four members from one of the families possessed a very large deletion that also involved GPR15, $5 \mathrm{Mb}$ upstream from exon 1 of PROS1. Evidence that $P R O S 1$ deletions might involve nearby genes up to at 
least $6.5 \mathrm{~kb}$ upstream was found before (Johansson et al. 2005; Yin et al. 2007; Yoo et al. 2009), but deletions larger than that were not reported. On the basis of the available data it is not possible to delineate how far the deletion extends beyond GPR15, but this result illustrates that some PS deficient families may have quite large deletions of chromosome 3. We do not have access to further clinical information from this family but it is possible that, because the deleted genes are all in a haploinsufficiency state, no other inherited diseases are apparent. It may be worthwhile in the future to evaluate selected PS deficient patients for the presence of other inherited disorders.

Although more than 200 mutations have been described in PS deficient patients, less than 5\% are gross deletions or duplications [Gandrille et al. 2000; Stenson et al. 2009 at HGMD (http://www.hgmd.cf.ac.uk/ac. Accessed 12 May 2009)]. Until 2005, only two large deletions were described in PROS1 (Ploos van Amstel et al. 1989; Schmidel et al. 1991). One of the likely reasons for this is that the detection technique, i.e. Southern blotting, is laborious and time-consuming. Moreover, Southern blots of PROS1 can not be easily interpreted because of the presence of the PS pseudogene.

Johansson et al. (2005) found large deletions in three out of eight investigated PS deficient families (38\%, all type I and mixed type I/III deficiency), who were PROS1 mutation-negative, suggesting that CNVs are an important factor in PS deficiency. These authors performed a segregation analysis using a dense set of SNPs and microsatellite markers and this approach proved to be efficient in some families. In other families the markers were not informative, showing the limitations of the use of segregation analysis. Furthermore, PROS1 is not directly targeted and deletions/ duplications of exons that are not covered by the microsatellite markers could easily be missed.

Three recent case-reports document two large deletions and one large duplication in PROS1 (Choung et al. 2008; Yin et al. 2007; Yoo et al. 2009). In these three studies, MLPA was used to screen for CNVs, underlining the usefulness of this technique for the examination of large gene rearrangements, even in a single patient. In the present study, we provided further evidence that gross CNVs are an important cause of PS deficiency in both families and isolated cases. We found deletions or duplications in $50 \%$ of the type I (5 out of 10), and $12.5 \%$ of the type III deficient (1 out of 8 ) point mutation-negative probands, suggesting that gene deletions are less common in type III families. This is, of course, not surprising as type III individuals have (near) normal levels of total PS, which is not easily reconciled with a gene deletion. It is also interesting to note that the only type III deficient patient with a CNV was an isolated proband, which does not exclude that it comes from a family with mixed type I/III deficiency.
The present panel of patients was drawn from a large set of French PS deficient individuals. Eighteen probands with a high probability of having a hereditary PS deficiency were selected. In $33 \%$ of the probands we found a CNV, showing that deletions/duplications are common in patients with putative hereditary PS deficiency. However, one should take care in extrapolating those numbers to consecutive patients with PS deficiency. Together, it seems to be worthwhile to include MLPA as a screening tool when investigating the molecular bases of hereditary PS deficiency.

We can only speculate on the reasons why CNVs occur quite frequently in the PROSI gene. Out of the five deletions and one duplication, three involved the complete gene, and one of these extends at least $5 \mathrm{Mb}$ to the $5^{\prime}$ (telomeric)-direction. Previous studies have also shown large deletions of PROS1 involving exon 1 and nearby genes (Johansson et al. 2005; Yin et al. 2007; Yoo et al. 2009) which gave rise to the idea that there could be a rearrangement focus somewhere telomeric to the NSUN3 gene (Yoo et al. 2009), but this claim was never objectively analyzed. In the remaining cases, exons 4,9 , and 11 where always involved. Thus, a hotspot for rearrangement might exist somewhere in these regions of PROS1. Further, the first case of PS deficiency due to a translocation [t(3;21)(q11.2; 22$)]$ was recently described (Hurtado et al. 2009), reinforcing the idea that the PROSI locus may be prone to structural changes. It has been shown that highly homologous low copy repeat structures, as well as AT-rich palindromes and peri-centromeric repeats are located at breakpoints of rearrangement leading to both homologous recombination and non-homologous end joining rearrangements mechanisms (Shaw and Lupski 2004).

Despite that this paper and those that precede it now report that CNVs are quite common in PS deficiency, there remains a large part of PS deficiency with unknown genetic causes. There are several possible reasons for this. First, the MLPA technique that was used did cover most, but still not all of the exons, so it remains possible that small deletions that hit these exons are often present in the remaining cases. The reason that some exons are not covered has to do with interference by the PS pseudogene in the MLPA reactions or with difficulty in examining AT rich regions. Secondly, the promoter region of $P R O S 1$ was only recently characterized and perhaps mutations in this region are quite common. Mutation analysis in the past has only poorly covered this region of the gene (de Wolf et al. 2006; Tatewaki et al. 2003). Thirdly, inversions of parts of the gene can not be ruled out by the MLPA technique as this does not change the copy numbers of the exons. Finally, recombination between gene and pseudogene may go unnoticed with the currently available detection techniques. 
In conclusion, this study confirms that gross gene abnormalities in PROS1 are common in PS deficient patients and it appears that MLPA is a useful tool in direct screening for copy number changes in PROS1. The qPCR confirmed the results, which underlines the accuracy of MLPA as a screening tool.

Acknowledgments We are specially grateful to G. T. M. Wagenaar and Y. P. de Visser from the Department of Pediatrics, Division of Neonatology, Leiden University Medical Center, The Netherlands, for their kind help on establishing the assay for the qPCR reaction and for the analysis of the results. This study was supported by the Dutch Heart Foundation (grant number 2006B160) and by a Transatlantic Network for Excellence in Cardiovascular Research grant from Fondation Leducq, Paris, France (LINAT project).

Open Access This article is distributed under the terms of the Creative Commons Attribution Noncommercial License which permits any noncommercial use, distribution, and reproduction in any medium, provided the original author(s) and source are credited.

\section{References}

Bertina RM (1990) Nomenclature proposal for protein S deficiency. XXXVI Annual meeting of Scientific and Standardization Committee of the International Society for Thrombosis and Haemostasis, June; Barcelona, Spain

Borgel D, Duchemin J, Alhenc-Gelas M, Matheron C, Aiach M, Gandrille S (1996) Molecular basis for protein S hereditary deficiency: genetic defects observed in 118 patients with type I and type IIa deficiencies. The French network on molecular abnormalities responsible for protein $\mathrm{C}$ and protein $\mathrm{S}$ deficiencies. J Lab Clin Med 128:218-227

Choung HS, Kim HJ, Gwak GY, Kim SH, Kim DK (2008) Inherited protein $\mathrm{S}$ deficiency as a result of a large duplication mutation of the PROS1 gene detected by multiplex ligation-dependent probe amplification. J Thromb Haemost 6:1430-1432

Comp PC, Doray D, Patton D, Esmon CT (1986) An abnormal plasma distribution of protein $\mathrm{S}$ occurs in functional protein $\mathrm{S}$ deficiency. Blood 67:504-508

Dahlbäck B (2000) Blood coagulation. Lancet 355:1627-1632

Dahlbäck B, Stenflo J (1981) High molecular weight complex in human plasma between vitamin K-dependent protein $\mathrm{S}$ and complement component C4b-binding protein. Proc Natl Acad Sci USA 78:2512-2516

de Visser YP, Walther FJ, Laghmani EH, van Wijngaarden S, Nieuwland K, Wagenaar GT (2008) Phosphodiesterase-4 inhibition attenuates pulmonary inflammation in neonatal lung injury. Eur Respir J 31:633-644

de Wolf CJ, Cupers RM, Bertina RM, Vos HL (2006) The constitutive expression of anticoagulant protein $\mathrm{S}$ is regulated through multiple binding sites for Sp1 and Sp3 transcription factors in the protein S gene promoter. J Biol Chem 281:17635-17643

den Dunnen JT, Antonarakis SE (2000) Mutation nomenclature extensions and suggestions to describe complex mutations: a discussion. Hum Mutat 15:7-12

Duchemin J, Borg JY, Borgel D, Vasse M, Lévèque H, Aiach M, Gandrille S (1996) Five novel mutations of the protein $S$ active gene (PROS 1) in 8 Norman families. Thromb Haemost 75:437444

Dykes AC, Walker ID, McMahon AD, Islam SI, Tait RC (2001) A study of protein $\mathrm{S}$ antigen levels in 3788 healthy volunteers: influence of age, sex and hormone use, and estimate for prevalence of deficiency state. Br J Haematol 113:636-641

Esmon CT (1987) The regulation of natural anticoagulant pathways. Science 235:1348-1352

Espinosa-Parrilla Y, Morell M, Souto JC, Tirado I, Fontcuberta J, Estivill X, Sala N (1999) Protein S gene analysis reveals the presence of a cosegregating mutation in most pedigrees with type I but not type III PS deficiency. Hum Mutat 14:30-39

Gandrille S, Borgel D, Eschwege-Gufflet V, Aillaud M, Dreyfus M, Matheron C, Gaussem P, Abgrall JF, Jude B, Sie P, Toulon P, Aiach M (1995) Identification of 15 different candidate causal point mutations and three polymorphisms in 19 patients with protein $S$ deficiency using a scanning method for the analysis of the protein S active gene. Blood 85:130-138

Gandrille S, Borgel D, Sala N, Espinosa-Parrilla Y, Simmonds R, Rezende S, Lind B, Mannhalter C, Pabinger I, Reitsma PH, Formstone C, Cooper DN, Saito H, Suzuki K, Bernardi F, Aiach M (2000) Protein S deficiency: a database of mutations-summary of the first update. Thromb Haemost 84:918

García de Frutos P, Fuentes-Prior P, Hurtado B, Sala N (2007) Molecular basis of protein $S$ deficiency. Thromb Haemost 98:543-556

Gómez E, Poort SR, Bertina RM, Reitsma PH (1995) Identification of eight point mutations in protein $\mathrm{S}$ deficiency type $\mathrm{I}$-analysis of 15 pedigrees. Thromb Haemost 73:750-755

Hoebeeck J, van der Luijt R, Poppe B, De Smet E, Yigit N, Claes K, Zewald R, de Jong GJ, De Paepe A, Speleman F, Vandesompele J (2005) Rapid detection of VHL exon deletions using real-time quantitative PCR. Lab Invest 85:24-33

Hurtado B, Nadal M, Margarit E, Sanchez A, Abasolo N, Garcia N, Domenech P, Sala N (2009) First case of protein S deficiency due to a translocation $\mathrm{t}(3 ; 21)(\mathrm{q} 11.2 ; \mathrm{q} 22)$. Thromb Haemost 101:977979

Johansson AM, Hillarp A, Säll T, Zöller B, Dahlbäck B, Halldén C (2005) Large deletions of the PROS1 gene in a large fraction of mutation-negative patients with protein $\mathrm{S}$ deficiency. Thromb Haemost 94:951-957

Lane DA, Mannucci PM, Bauer KA, Bertina RM, Bochkov NP, Boulyjenkov V, Chandy M, Dahlbäck B, Ginter EK, Miletich JP, Rosendaal FR, Seligsohn U (1996) Inherited thrombophilia: Part 1. Thromb Haemost 76:651-662

Lanke E, Johansson AM, Hillarp A, Lethagen S, Zöller B, Dahlbäck B, Halldén C (2004) Co-segregation of the PROS1 locus and protein $\mathrm{S}$ deficiency in families having no detectable mutations in PROS1. J Thromb Haemost 2:1918-1923

Maurissen LFA, Thomassen MC, Nicolaes GAF, Dahlback B, Tans G, Rosing J, Hackeng TM (2008) Re-evaluation of the role of the protein $\mathrm{S}-\mathrm{C} 4 \mathrm{~b}$ binding protein complex in activated protein $\mathrm{C}$-catalyzed factor Va-inactivation. Blood 111:3034-3041

Persson KE, Dahlbäck B, Hillarp A (2003) Diagnosing protein S deficiency: analytical considerations. Clin Lab 49:103-110

Ploos van Amstel JK, van der Zanden AL, Bakker E, Reitsma PH, Bertina RM (1987) Two genes homologous with human protein S cDNA are located on chromosome 3. Thromb Haemost 58:982-987

Ploos van Amstel HK, Huisman MV, Reitsma PH, Wouter ten CJ, Bertina RM (1989) Partial protein S gene deletion in a family with hereditary thrombophilia. Blood 73:479-483

Ploos van Amstel HK, Reitsma PH, van der Logt CP, Bertina RM (1990) Intron-exon organization of the active human protein $S$ gene PS alpha and its pseudogene PS beta: duplication and silencing during primate evolution. Biochemistry 29:7853-7861

Reitsma PH, Ploos van Amstel HK, Bertina RM (1994) Three novel mutations in five unrelated subjects with hereditary protein $\mathrm{S}$ deficiency type I. J Clin Invest 93:486-492

Schmidel DK, Tatro AV, Phelps LG, Tomczak JA, Long GL (1990) Organization of the human protein $\mathrm{S}$ genes. Biochemistry 29:7845-7852 
Schmidel DK, Nelson RM, Broxson EH Jr, Comp PC, Marlar RA, Long GL (1991) A 5.3-kb deletion including exon XIII of the protein $\mathrm{S}$ alpha gene occurs in two protein S-deficient families. Blood 77:551-559

Schouten JP, McElgunn CJ, Waaijer R, Zwijnenburg D, Diepvens F, Pals G (2002) Relative quantification of 40 nucleic acid sequences by multiplex ligation-dependent probe amplification. Nucleic Acids Res 30:e57

Seligsohn U, Lubetsky A (2001) Genetic susceptibility to venous thrombosis. N Engl J Med 344:1222-1231

Shaw CJ, Lupski JR (2004) Implications of human genome architecture for rearrangement-based disorders: the genomic basis of disease. Hum Mol Genet 13 (Spec No 1):R57-R64

Simmonds RE, Zöller B, Ireland H, Thompson E, de Frutos PG, Dahlbäck B, Lane DA (1997) Genetic and phenotypic analysis of a large (122-member) protein S-deficient kindred provides an explanation for the familial coexistence of type I and type III plasma phenotypes. Blood 89:4364-4370
Stenson PD, Mort M, Ball EV, Howells K, Phillips AD, Thomas NS, Cooper DN (2009) The human gene mutation database: 2008 update. Genome Med 1:13

Tatewaki H, Tsuda H, Kanaji T, Yokoyama K, Hamasaki N (2003) Characterization of the human protein $\mathrm{S}$ gene promoter: a possible role of transcription factors Sp1 and HNF3 in liver. Thromb Haemost 90:1029-1039

ten Kate MK, van der Meer J (2008) Protein S deficiency: a clinical perspective. Haemophilia 14(6):1222-1228

Yin T, Takeshita S, Sato Y, Sakata T, Shin Y, Honda S, Kawasaki T, Tsuji H, Kojima T, Madoiwa S, Sakata Y, Murata M, Ikeda Y, Miyata T (2007) A large deletion of the PROS1 gene in a deep vein thrombosis patient with protein S deficiency. Thromb Haemost 98:783-789

Yoo JH, Kim HJ, Maeng HY, Kim YA, Sun YK, Song JW, Choi JR, Kim SH, Lee KA (2009) Hereditary protein S deficiency from a novel large deletion mutation of the PROS1 gene detected by multiplex ligation-dependent probe amplification (MLPA). Thromb Res 123:793-795 